\title{
Moroccan Teachers of English Acceptance and Readiness to Use MOOCs for Continuing Professional Development
}

\author{
Elhassane EL Hilali*, Mohammed Moubtassime \\ Department of English, Sidi Mohamed Ben Abdellah University, Fez, Morocco \\ Received November 15, 2020; Revised March 11, 2021; Accepted April 22, 2021
}

\begin{abstract}
Cite This Paper in the following Citation Styles
(a): [1] Elhassane EL Hilali, Mohammed Moubtassime, "Moroccan Teachers of English Acceptance and Readiness to Use MOOCs for Continuing Professional Development," Universal Journal of Educational Research, Vol. 9, No. 5, pp. 891 - 900, 2021. DOI: 10.13189/ujer.2021.090501.
\end{abstract}

(b): Elhassane EL Hilali, Mohammed Moubtassime (2021). Moroccan Teachers of English Acceptance and Readiness to Use MOOCs for Continuing Professional Development. Universal Journal of Educational Research, 9(5), 891 - 900. DOI: 10.13189/ujer.2021.090501.

Copyright $\bigcirc 2021$ by authors, all rights reserved. Authors agree that this article remains permanently open access under the terms of the Creative Commons Attribution License 4.0 International License

\begin{abstract}
MOOCs (Massive Open Online Courses) have become a modern concept in education and new meaningful learning environment for technology-enhanced learning, where huge numbers of users worldwide access free, online-based, open content generated by world-renowned institutions. To provide successful MOOC environments requires recognizing the learners' motivations to utilize MOOCs programs. Because of the scarcity of research on MOOCs' use for teacher's professional development, it makes use of information technologies to enhance the learning experience for teachers and students. The present study seeks to investigate acceptance and readiness towards MOOCs' use for continuing professional development besides the degree to which teachers benefit from MOOCs. A survey questionnaire based on TAM (Technology Acceptance Model) [8] is employed as a data collection instrument regarding Usefulness(U), Perceived Ease of Use (PEU), User Satisfaction and Attribute of Usability (USAU) of MOOCs in professional development. The population is senior high secondary school teachers of English from different regions of Morocco. The analysis of the results obtained from various statistical tests revealed that teachers accepted MOOCs programs for continuing professional development with an objective of developing, acquiring and consolidating the necessary insight, skills and competencies required in modern teaching for 21-century education. Most teachers attending MOOCs' programs for
\end{abstract}

continuing professional development were satisfied with the results they obtained from their participation. They also reported that MOOCs programs had an unequivocal and effective impact on their professional and career development.

Keywords MOOCs, Moroccan Teachers, Professional Development, Teaching Practices, Capacity Development

\section{Introduction}

MOOCs' benefits for teacher's professional development have been highlighted in many studies and various educational contexts worldwide. According to [13], MOOCs have several advantages. They can help improve teachers' practices in classroom context by exposing them to a large assortment of teaching styles, methodologies, techniques and approaches, and support their technology use for instructional purposes. Accordingly, teachers' uses of MOOCs proved to be strong determinants of MOOCs' adoption for continuing professional development.

Teacher's professional development itself is a newly established and developing research field in several countries. According to [11], no one fixed definition is available for teacher's professional development concept. 
Yet, for consistency, clarity and simplicity, teachers' continuing professional development throughout this current research paper designates learning and training opportunities that help teachers of English grow professionally through MOOCs' use. Likewise, the Moroccan NCET (National Charter of Education and Training) emphasized the significance of teacher's professional development:

Education staffs at every level of education receive two categories of training:

- Short training sessions to uplift the skills are needed in the teaching field. These sessions last for thirty hours, divided accurately during the whole school year.

- In-depth retraining sessions at least once every three years.

All the training sessions will be scheduled in consonance with the leading-edge theories and effective practices in education. The insights and views of the parties involved in the Moroccan educational system ought to be considered. Cooperatively with the experts in the relevant fields of study, parents should bring forth suggestions by following the main goals and principles of the Moroccan educational system.

The trainings are to be hosted in nearby centers and make use of all sorts of equipment available with the suitable time management." (Trans.mine)[3]

Many various studies highlighted the momentousness of MOOCs programs in teacher's professional development. For instance, the United States' Department of Education, in regard to continuing professional development, reported that $97 \%$ of teachers took part in many professional development trainings which have to do with teaching over the last 12 months [2]. Similarly, the NSDC (National Staff Development Council) reported that $92 \%$ of teachers joined some professional development forms over the last 12 months. Still, only $31 \%$ participated in traditional professional development occasions like taking courses at university [6].

The support given to MOOCs programs for continuing professional development is clearly seen from the way providers of these MOOCs have changed their strategy of providing traditional learning only to even providing blended-learning opportunities and career development or, in other terms, lifelong learning. Another study by [10] showed that more than $83 \%$ of MOOCs participants hitherto have a two or four-year post-secondary degree, which explains that the participant teachers in this current paper have already been using MOOCs to expand their learning above and beyond existing degrees. Such a study divulges that MOOCs programs have transformed traditional education and opened new horizons regarding teacher's professional growth. Therefore, this current paper seeks to introduce plan principles that will, surely, allow MOOCs to turn into a practical tool to offer cost-effective, high-quality opportunities of professional development for Moroccan teachers of English.

\subsection{Aims of the Study}

This paper attempted to investigate any relationship existing between MOOCs' use and teachers of English' professional development. To put it differently, the current paper tries to probe the main role of MOOCs programs in teacher's continuing professional development through investigating Moroccan teachers' acceptance and preparedness to use those courses.

To reach this goal, the paper strived to respond to the following research questions:

a) How do personal characteristics affect teachers' willingness and preparedness to adopt and use MOOCs for continuing professional development?

b) How can TAM framework be utilised to explain teachers' acceptance of MOOCs programs for professional development?

\subsection{Significance of the Study}

MOOCs for teacher's professional development are new pathways in the Moroccan educational system since they encourage technology use inside and out the classroom. Consequently, such kind of professional development training and learning becomes a significant experience to explore both regarding utility and practicality. Besides, and since most teachers are not well-informed about and familiar with technology use for pedagogical purposes, MOOCs proved significant to be helpful and useful programs for professional growth regarding this domain.

\section{Review of Literature}

Recently, a growing interest has been noticed in teacher's continuing professional development worldwide through MOOCs' use. As a recent online education mode in the distance learning field, MOOCs allowed many people to learn, share, discuss, and access a broad-spectrum of courses they are interested in wherever they are [21]. Moreover, MOOCs have successfully attracted many learners from different educational and cultural backgrounds based on certain motivations towards the course selected [14]. They offer many alternatives to keep teachers updated about new pedagogies, approaches and the mastery of technology use for instruction in classrooms. For teachers of foreign languages, the merits of MOOCs' use are countless. They can help them save learning resources, improve sharing and scheduling capacity of educational learning resources, arrange teaching time and improve their teaching efficiency [9]. According to [12], not only MOOCs help in offering site-based learning, but they also provide teachers with self-directed and autonomous professional development. 
Following this thought, MOOCs can remarkably change and alter teachers' perceptions and attitudes as regards professional development via capacity and skills development [17]. For [23], MOOCs have "a promising future in its application to teacher professional development, and it will promote the reform on teacher education to some extent. Teacher professional development is always guided by national policies. Therefore, supportive policies are the base and presupposition for the application of MOOC to teacher professional development".

The increase of interest among teachers in taking MOOCs for continuing professional development emanates from a set of essential characteristics related to MOOCs namely openness and gratuitousness. The latter two terms refer to and describe how teachers face the charges and time-related problems regarding professional development journeys [16]. As an effect of their openness, gratuitousness, design, and construction, participant teachers can easily get involved in a rich, motivating learning experience, and free and open environment. Accordingly, the link between MOOCs and continuing professional development may be explained in consonance with a win-win situation where teachers learn, and technology is used [15].

There have been many research studies that discussed the issues of adopting and uptaking technology in education, especially for teacher's professional development. These cover studies that have a relation with the effects of teachers' training [5], levels of resources [4], teachers' pedagogies and practices [19], and teachers' attitudes [20]. Many, among these studies, have explained that despite teachers' training programs, the opportunities of professional development besides the increase of technology resources, there has been unsatisfactory slow technology uptake and adoption at schools by most of teachers worldwide. This slow technology adoption in schools at large and for professional development, particularly, comes out of different internal and external factors, such as resistance to change, negative attitude toward technology and technology use, inadequate resources, lack of experience and skill in technology use, and above all absence of readiness and desire in adopting and utilising technology for professional growth. These factors have been identified in many research studies as strong determinants in adopting and utilising technology on account of the influence they have on teachers' decision in using technology for instruction or technology for personal professional growth.

For the purpose of investigating the impact that these factors have on teachers' adoption and MOOCs' use for professional development, the TAM is utilised as a theoretical framework to guide and inform the paper's thesis and also to underpin the knowledge base of the phenomenon under investigation. [7] proposed this model to elucidate the potential user's behavioral willingness to use technological innovation, and also explains the individual's preparedness and acceptance steaming from a technology form. TAM (Technology Adoption Model) is mainly gleaned from the TRA (Theory of Reasoned Action), a psychological theory that seeks to explain behaviors and, at the same time, attitudes. Similarly, the PBT (Planned Behavior Theory), in which it adopts a cognitive approach to explain behaviors that pinpoint individuals' attitudes, motivations, and beliefs, was part and parcel of this study's theoretical framework. At its beginning, TAM involved two primary constructs: Perceived Usefulness and Perceived Ease of Use, that are derived as well from Bandura's Self Efficacy Theory [1], which defines perceived ease of use as « the judgments of how well one can execute courses of action required to deal with prospective situation» and from [18] research paper which explains complexity (described as ease of use) as " the degree to which an innovation is perceived as relatively difficult to understand and use». Figure 1 below explains clearly the relationship existing between the different constructs inherent in the framework of TAM used for this current study.

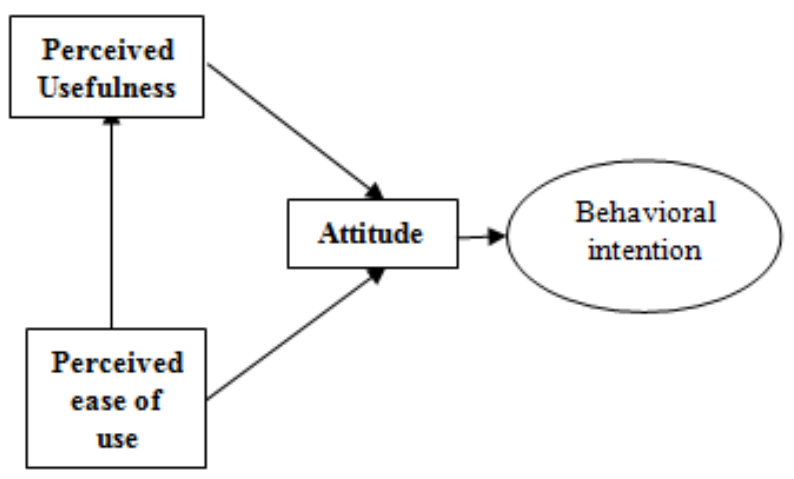

Figure 1. Technology Adoption Model (Davis, 1989)

\section{Research Methodology}

The current paper was designed with an objective to explore Moroccan teachers of English acceptance and preparedness to adopt MOOCs for their journeys of continuing professional growth. It employed a quantitative method by using many data collection tools such as Google forms, Facebook and WhatsApp groups, and online groups of practice. The present paper adopted the theoretical framework of TAM [8] to guide and orient this research. The populations targeted are senior high secondary school teachers of English working in public schools dispersed across twelve administrative regions all over Morocco. The participants number reached 312, grouped as 90 females and 222 males.

\section{Findings and Discussions}

Continuing Teacher's Professional Development (CTPD) 
has nowadays become one among the major policy priorities within the educational systems worldwide. But keeping teachers up-to-date, professionally, and offering them opportunities for professional development on a regular basis is the biggest challenge. MOOCs programs can, notably, be the unique solution and possibility to obverse the traditional methods of professional development that have been received by teachers in teachers' training centers. This optimism assumes that MOOCs' use can facilitate mass training of teachers in conformity with their convenience, availability and ease. In addition, MOOCs-based trainings are easy to take on and adapt to diverse cultures, languages and educational contexts. Concordantly, and by considering these hypotheses, MOOCs' uses for Moroccan teachers of English' continuing professional growth is explored as regards a batch of determinant variables like gender, age, teaching experience and region of work.

\subsection{Research Question 1 \#}

How do personal characteristics affect teachers' willingness and preparedness to utilize and adopt MOOCs programs for their professional development?

\subsubsection{MOOCs' use for teacher's professional development based on gender}

Table 1. MOOCs' use based on gender

\begin{tabular}{|c|c|c|c|c|c|}
\hline \multicolumn{2}{|c|}{} & Frequency & Percent & $\begin{array}{c}\text { Valid } \\
\text { Percent }\end{array}$ & $\begin{array}{c}\text { Cumulative } \\
\text { Percent }\end{array}$ \\
\hline \multirow{4}{*}{ Valid } & Male & 222 & 71,2 & 71,2 & 71,2 \\
\cline { 2 - 6 } & Female & 90 & 28,8 & 28,8 & 100,0 \\
\cline { 2 - 6 } & Total & 312 & 100,0 & 100,0 & \\
\hline
\end{tabular}

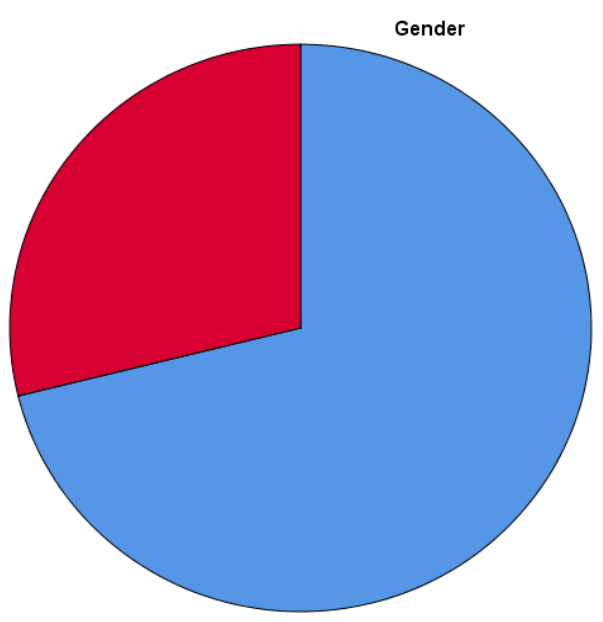

Figure 2. MOOCs' use based on gender
Examining MOOCs' use for teacher's continuing professional development in regard to gender revealed significant variations between males and females. Females' participation reached 90, while males reached 222 . This indicates that MOOCs' use for teacher's continuing professional development is male-dominated and oriented experience. This is probably due to several reasons related to cultural and social constraints such as female working conditions, home responsibilities technophobia. Table 1 and Figure 2 clarify the distribution of MOOCs' use for teacher's continuing professional development based on gender.

The findings obtained from descriptive statistics regarding MOOCs' use for teacher's professional development in regard to gender reached significance as well in inferential statistics. One-Way analysis of variance method was utilised to analyze differences among the two groups of teachers at the professional development level.

As evidenced in Table 2 below, mean differences between the two groups were statistically significant since the sig value reached high significance $[\mathrm{F}(29,282)=6,442$ $\mathrm{p}<.0005]$; therefore, a post-hoc Tukey test was performed to determine which group showed differences from the other group.

Table 2. One-Way ANOVA: MOOCs' use for professional development based on gender

\begin{tabular}{|c|c|c|c|c|c|}
\hline \multicolumn{7}{|c|}{ Gender } \\
\hline & $\begin{array}{c}\text { Sum of } \\
\text { Squares }\end{array}$ & Df & $\begin{array}{c}\text { Mean } \\
\text { Square }\end{array}$ & F & Sig. \\
\hline $\begin{array}{c}\text { Between } \\
\text { Groups }\end{array}$ & 25,517 & 29 &, 880 & 6,442 &, 000 \\
\hline $\begin{array}{c}\text { Within } \\
\text { Groups }\end{array}$ & 38,521 & 282 &, 137 & & \\
\hline Total & 64,038 & 311 & & & \\
\hline
\end{tabular}

4.1.2. MOOCs' use for teacher's professional development based on age

To probe the differences existing between respondents regarding MOOCs' use for teacher's professional development based on age, descriptive statistics were utilized first (see Table 3 below). MOOCs' uses for continuing professional development based on age indicated significant variations in which different-age groups differ from one another in keeping with the recurrence of MOOCs' use and usage. Age group 2 (31-40 years old) scored the highest while the fourth age group (Over 50 years old) scored the lowest. This indicates that age is a consequential variable that affects MOOCs' uses by teachers for continuing professional development. Table 4 and Figure 3 below explain clearly the difference in the recurrence of MOOCs' uses by teachers for continuing professional development based on age. 
Table 3. MOOCs' use based on age

\begin{tabular}{|c|c|c|c|c|c|}
\hline \multicolumn{2}{|c|}{} & Frequency & Percent & Valid Percent & Cumulative Percent \\
\hline \multirow{4}{*}{ Valid } & $20-30$-Years-Old & 90 & 28,8 & 28,8 & 28,8 \\
\cline { 2 - 6 } & $31-40$-Years-Old & 123 & 39,4 & 39,4 & 68,3 \\
\cline { 2 - 6 } & $41-50$-Years-Old & 75 & 24,0 & 24,0 & 92,3 \\
\cline { 2 - 6 } & Over-50-Years-Old & 24 & 7,7 & 7,7 & 100,0 \\
\cline { 2 - 6 } & Total & 312 & 100,0 & 100,0 & \\
\hline
\end{tabular}

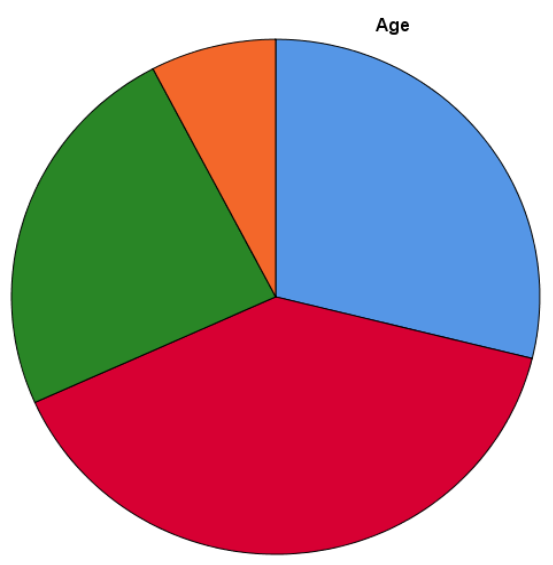

Figure 3. MOOCs' use based on age

Table 4. One-Way ANOVA: MOOCs' use for professional development based on age

\begin{tabular}{|c|c|c|c|c|c|}
\hline \multicolumn{7}{|c|}{ Age } \\
\hline & $\begin{array}{c}\text { Sum of } \\
\text { Squares }\end{array}$ & Df & $\begin{array}{c}\text { Mean } \\
\text { Square }\end{array}$ & F & Sig. \\
\hline $\begin{array}{c}\text { Between } \\
\text { Groups }\end{array}$ & 51,342 & 29 & 1,770 & 2,422 &, 000 \\
\hline $\begin{array}{c}\text { Within } \\
\text { Groups }\end{array}$ & 206,168 & 282 &, 731 & & \\
\hline Total & 257,510 & 311 & & & \\
\hline
\end{tabular}

To ascertain whether the existing differences between respondents' use of MOOCs for continuing professional development based on their age were statistically significant or not, One-Way analysis of variance (ANOVA) was used. Table 4 details the ANOVA analysis findings. These findings clearly explain the differences existing between respondents were statistically significant since the sig value was $(.000),[F(29,282)=2,422, p=.000]$. Simply put, this indicates that young teachers tend to opt for
MOOCs programs for continuing professional development more than their older counterparts.

4.1.3. MOOCs' use for teacher's professional development based on teaching experience

MOOCs' use for professional growth or development was also examined based on teaching experience. The findings obtained from descriptive statistics showed that teaching experience as a dependent variable affected teachers' use of MOOCs programs for continuing professional development significantly. This obviously means that the more teachers grow in their teaching experience, the less they use MOOCs for professional development. Otherwise stated, the more teachers become seniors, the less they use technology. Table 5 and Figure 4 indicate that seniority affects teachers' uses of MOOCs programs for continuing professional development significantly.

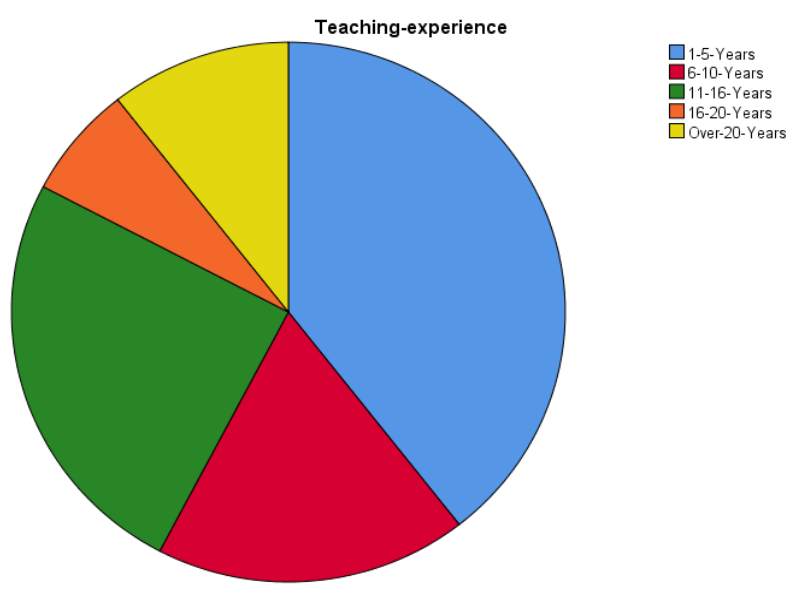

Figure 4. MOOCs' use based on teaching experience 
Table 5. MOOCs' use based on teaching experience

\begin{tabular}{|c|c|c|c|c|c|}
\hline \multicolumn{2}{|c|}{} & Frequency & Percent & Valid Percent & Cumulative Percent \\
\hline \multirow{4}{*}{ Valid } & $1-5$-Years & 123 & 39,4 & 39,4 & 39,4 \\
\cline { 2 - 6 } & $6-10-$ Years & 57 & 18,3 & 18,3 & 57,7 \\
\cline { 2 - 6 } & $11-16-Y e a r s$ & 78 & 25,0 & 25,0 & 82,7 \\
\cline { 2 - 6 } & $16-20$-Years & 21 & 6,7 & 6,7 & 89,4 \\
\cline { 2 - 6 } & Over-20-Years & 33 & 10,6 & 10,6 & 100,0 \\
\cline { 2 - 6 } & Total & 312 & 100,0 & 100,0 & \\
\hline
\end{tabular}

The descriptive statistics significance reached inferential statistics as well. The One-Way ANOVA analysis indicated that seniority or long years spent in the profession affected teachers' use of MOOCs programs for continuing professional development (table 6) significantly. In congruence with the obtained findings from this analysis, the sig value was very significant since it was $(, 000)[\mathrm{F}(29$, $282)=3.105, \mathrm{p}=.000]$.

Table 6. One-Way ANOVA: MOOCs' use for professional development based on teaching experience

\begin{tabular}{|c|c|c|c|c|c|}
\hline \multicolumn{7}{|c|}{ Teaching Experience } \\
\hline & $\begin{array}{c}\text { Sum of } \\
\text { Squares }\end{array}$ & Df & $\begin{array}{c}\text { Mean } \\
\text { Square }\end{array}$ & F & Sig. \\
\hline $\begin{array}{c}\text { Between } \\
\text { Groups }\end{array}$ & 133,709 & 29 & 4,611 & 3,105 &, 000 \\
\hline $\begin{array}{c}\text { Within } \\
\text { Groups }\end{array}$ & 418,753 & 282 & 1,485 & & \\
\hline Total & 552,462 & 311 & & & \\
\hline
\end{tabular}

4.1.4. MOOCs' Use for teacher's professional development based on region

MOOCs' use for professional growth teachers of English based on their region of work was also examined. The obtained results revealed significant findings in descriptives which table 7 and Figure 5 below show. The region of Béni-Ellal-Khnifra scored the highest if compared to other regions, especially the Oriental-Region which scored the lowest in this current study. This probably means that teachers of English in this vast region (Béni-Mellal-Khnifra) are more interested in using these programs for their continuing professional development considering that the preponderance of this region is rural and the only appropriate moments for teachers so as to busy themselves is via joining online groups of practice through MOOCs and other social media websites or platforms.

Table 7. MOOCs' use for professional development based on region

\begin{tabular}{|c|c|c|c|c|c|}
\hline \multicolumn{6}{|c|}{ Region-where-you-work } \\
\hline & & Frequency & Percen & $\begin{array}{c}\text { Valid } \\
\text { Percent }\end{array}$ & $\begin{array}{c}\text { Cumulative } \\
\text { Percent }\end{array}$ \\
\hline \multirow{11}{*}{ Valid } & Tanger-Tétouan-Al-Hoceima & 3 & 1,0 & 1,0 & 1,0 \\
\hline & $\begin{array}{l}\text { Oriental-region- } \\
\text { (Oujda-Angad) }\end{array}$ & 3 & 1,0 & 1,0 & 1,9 \\
\hline & Fes-Meknes & 45 & 14,4 & 14,4 & 16,3 \\
\hline & Rabat-Salé-Kenitra & 9 & 2,9 & 2,9 & 19,2 \\
\hline & Béni-Mellal-Khénifra & 141 & 45,2 & 45,2 & 64,4 \\
\hline & Casablanca-Settat & 6 & 1,9 & 1,9 & 66,3 \\
\hline & Marrakech-Safi & 48 & 15,4 & 15,4 & 81,7 \\
\hline & Drâa-Tafilalet & 30 & 9,6 & 9,6 & 91,3 \\
\hline & Souss-Massa & 18 & 5,8 & 5,8 & 97,1 \\
\hline & Laâyoune-Sakia-El-Hamra & 9 & 2,9 & 2,9 & 100,0 \\
\hline & Total & 312 & 100,0 & 100,0 & \\
\hline
\end{tabular}




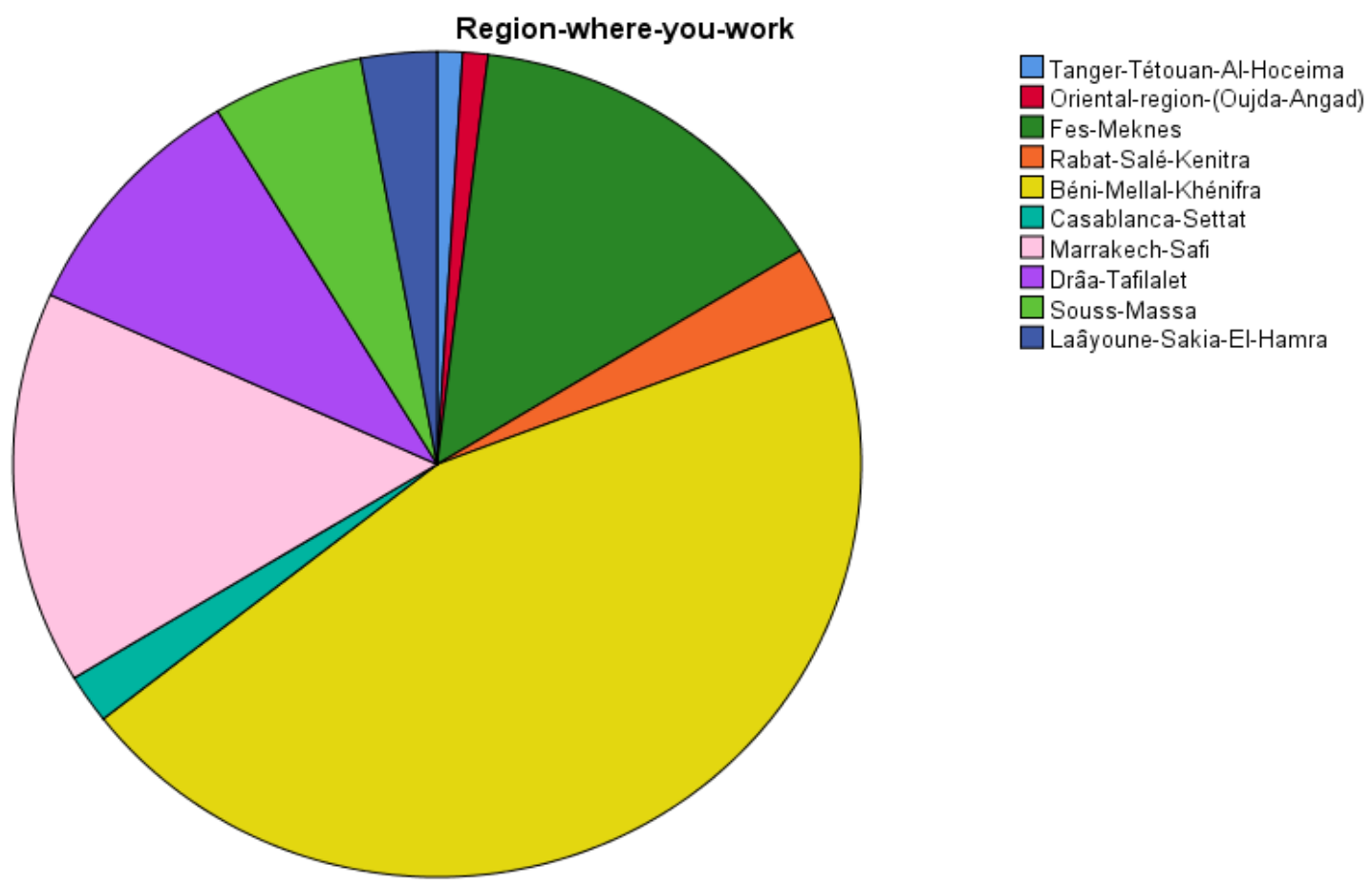

Figure 5. MOOCs' use for professional development based on region

The descriptive analysis yielded significant results (Table 7). This is clearly shown in table 8 of the One-Way ANOVA test, which results in $(, 000)[F(29,282)=6.042$, $\mathrm{p}=.000]$, a sign that indicates that teachers in countryside areas are more active, dynamic and eager to learn if compared to their counterparts in big cities where teachers are busy and cannot find time for personal professional development.

Table 8. One-Way ANOVA: MOOCs' use for professional development based on region

\begin{tabular}{|c|c|c|c|c|c|}
\hline \multicolumn{7}{|c|}{ Region-where-you-work } \\
\hline & $\begin{array}{c}\text { Sum of } \\
\text { Squares }\end{array}$ & Df & $\begin{array}{c}\text { Mean } \\
\text { Square }\end{array}$ & F & Sig. \\
\hline $\begin{array}{c}\text { Between } \\
\text { Groups }\end{array}$ & 466,901 & 29 & 16,100 & 6,042 &, 000 \\
\hline $\begin{array}{c}\text { Within } \\
\text { Groups }\end{array}$ & 751,445 & 282 & 2,665 & & \\
\hline Total & 1218,346 & 311 & & & \\
\hline
\end{tabular}

\subsection{Research Question 2 \#}

How can Technology Acceptance Model (TAM) be utilised to explain teachers' acceptance of MOOCs for their continuing professional development?

As a consequence of the literature review discussed earlier and in consonance with the results obtained in response to the research questions, there are several factors, which have been recognised as influencing elements when talking about MOOCs' use for continuing professional development. With an objective to investigate these factors deeply regarding teachers of English use of MOOCs programs for continuing professional development, we have employed TAM framework, which has been largely utilised in technology adoption studies to know teachers' attitudes towards MOOCs and why some use or don't use them for continuing professional development. This framework that is adopted in this present paper connects the perceived usefulness and ease of use to the attitude towards MOOCs' use for professional development. In other words, among the many variables that may influence system use, previous research suggests two determinants that are especially important, perceive ease of use and usefulness. According to [7], perceived usefulness is a primary determinant, and perceived ease of use is a secondary determinant of willingness to use technology. The obtained results vis - a- vis these two determinants are provided in table 9 .

\subsubsection{Perceived usefulness (PU)}

PU (Perceived usefulness) is defined here as the degree to which teachers believe that using MOOCs for professional development would enhance their job performance as teachers of English. Usefulness means the advantageous role MOOCs can play in teacher's professional development. According to TAM framework a tool that is perceived as useful is generally one for which a user believes in the existence of a positive use-performance relationship. Table 10 illuminates these determinants and the obtained findings in descriptive statistics.

\subsubsection{Perceived ease of use}

Perceived ease of use (PEU), in contrast, refers to the degree to which teachers believe that using MOOCs for 
professional development would be free of efforts. Ease of use designates, in this study, freedom from difficulty or great effort to understand or use MOOCs. The results obtained from descriptive statistics (See table 10 below) support the last-mentioned argument and shows that Moroccan teachers use MOOCs because they see in them numerous values (usefulness) and easiness to use (ease of use).

\subsubsection{Attitudes and general beliefs regarding the process of learning in MOOCs}

Among the major interesting questions about MOOCs is the question of teachers' general beliefs, attitudes, motivations, intentions and personal goals to learn for their own continuing professional growth in this unique and distinguished way. It is clear that different learners have different beliefs, attitudes, motivations, intentions, and personal goals that impact their learning through MOOCs' use for continuing professional development. Understanding Moroccan teachers' uniqueness in MOOCs' use for their continuing professional development would enable us with considerable scale information on the personalization of Moroccan teachers' use of MOOCs for continuing professional development, especially if we take into consideration that MOOC's classrooms are not replications of traditional classrooms in terms of mode of use, interaction, access to resources and others. According to the results obtained which are shown clearly in Table 11, the responders had a high commitment to MOOCs' use for continuing professional development.

Table 9. Descriptive statistics with regard to perceived usefulness

\begin{tabular}{|l|c|c|c|c|c|}
\hline & $\mathrm{N}$ & Minimum & Maximum & Mean & Std. Deviation \\
\hline 1.MOOCs'use-will-help-me-in-the-long run-of-my-career & 312 & 1 & 5 & 4,18 &, 865 \\
\hline $\begin{array}{l}\text { 2.MOOCs'use-will-boost-the- } \\
\text { teaching-and-learning-process }\end{array}$ & 312 & 1 & 5 & 4,20 &, 802 \\
\hline $\begin{array}{l}\text { 3.MOOCs'use-will-surely-contribute-to-my- } \\
\text { personal-success-in-the-future }\end{array}$ & 312 & 1 & 5 & 4,00 &, 856 \\
\hline \multicolumn{1}{|c|}{ Valid N (listwise) } & 312 & & & & \\
\hline
\end{tabular}

Table 10. Descriptive statistics related to perceived ease of use

\begin{tabular}{|l|c|c|c|c|c|}
\hline & $\mathrm{N}$ & Minimum & Maximum & Mean & Std. Deviation \\
\hline $\begin{array}{l}\text { 1.It-would-be-easy-for-me-to-become-s } \\
\text { killful-at- the-programs-of-MOOCs }\end{array}$ & 312 & 1 & 5 & 3,70 &, 866 \\
\hline $\begin{array}{l}\text { 2.I-believe-that-using-MOOCs-is-very-s } \\
\text { imple }\end{array}$ & 312 & 1 & 5 & 3,38 &, 882 \\
\hline $\begin{array}{l}\text { 3.I-believe-that-generally-using-MOOC } \\
\text { s -is-simple }\end{array}$ & 312 & 1 & 5 & 3,42 &, 841 \\
\hline \multicolumn{1}{|l}{ Valid N (listwise) } & 312 & & & \\
\hline
\end{tabular}

Table 11. Attitudes and general beliefs regarding the process of learning in MOOCs

\begin{tabular}{|c|c|c|c|c|c|}
\hline \multicolumn{6}{|c|}{ Descriptive Statistics } \\
\hline & $\mathrm{N}$ & Minimum & Maximum & Mean & $\begin{array}{c}\text { Std. } \\
\text { Deviation }\end{array}$ \\
\hline 1.I-find-that-MOOCs-programs-cause-me-a-great-satisfaction & 312 & 2 & 5 & 3,73 &, 738 \\
\hline $\begin{array}{l}\text { 2.I-would-like-to-learn-a-lot-from-MOOCs-but-with-minimal-learning- } \\
\text { Efforts }\end{array}$ & 312 & 1 & 5 & 3,52 & ,992 \\
\hline $\begin{array}{l}\text { 3.I-find-that-most-of-the-MOOCs-programs-for-teachers-professional- } \\
\text { development-are-appealing-and-I-am-prepared-to-allot-enough-time-to } \\
\text {-enrich-my-knowledge }\end{array}$ & 312 & 1 & 5 & 4,00 &, 810 \\
\hline $\begin{array}{l}\text { 4.I-dont-find-any-course-in-MOOCs-programs-appealing-therefore-I-d } \\
\text { o-the-minimum-I-can }\end{array}$ & 312 & 1 & 5 & 2,49 & ,972 \\
\hline $\begin{array}{l}\text { 5.I-compare-the-learning-process-in-MOOCs-to-a-real-classroom-cont } \\
\text { ext }\end{array}$ & 312 & 1 & 5 & 3,38 &, 860 \\
\hline $\begin{array}{l}\text { 6.I-allot-enough-time-to-learning-from-MOOCs-programs-because-I-fi } \\
\text { nd-them-very-appealing }\end{array}$ & 312 & 1 & 5 & 3,49 &, 810 \\
\hline $\begin{array}{l}\text { 7.I-look-for-professional-development-opportunities-in-MOOCs-progr } \\
\text { ams }\end{array}$ & 312 & 1 & 5 & 3,98 &, 785 \\
\hline $\begin{array}{l}\text { 8.I-believe-it-is-sufficient-to-have-minimal-basic-understandings-in-usi } \\
\text { ng-MOOCs-platforms }\end{array}$ & 312 & 1 & 5 & 3,35 & ,919 \\
\hline $\begin{array}{l}\text { 9.I-believe-lecturers-should-understand-that-teachers-are-not-going-to-1 } \\
\text { earn-things-which-they-will-not-use-in-their- } \\
\text { classrooms }\end{array}$ & 312 & 1 & 5 & 3,54 & ,910 \\
\hline $\begin{array}{l}\text { 10.I-usually-attend-MOOCs-with-several-questions-in-mind-and-I-am- } \\
\text { sure-they-will-be-answered-by-the-end-of-MOOCs-programs }\end{array}$ & 312 & 1 & 5 & 3,63 & ,846 \\
\hline $\begin{array}{l}\text { 11.I-turn-over-all-the-additional-reading-materials-recommended-by-M } \\
\text { OOCs-Facilitators }\end{array}$ & 312 & 1 & 5 & 3,19 & 879 \\
\hline $\begin{array}{l}\text { 12.I-think-exams-in-MOOCs-evaluate-teachers-achievements-effective } \\
\text { ly }\end{array}$ & 312 & 1 & 5 & 3,32 &, 836 \\
\hline Valid N (listwise) & 312 & & & & \\
\hline
\end{tabular}


Table 12. Threats and challenges towards using MOOCs

\begin{tabular}{|c|c|c|c|c|c|}
\hline \multicolumn{9}{|c|}{ Descriptive Statistics } & \multicolumn{1}{|c|}{ Std. Deviation } \\
\hline & $\mathrm{N}$ & Minimum & Maximum & Mean &, $\mathbf{9 8 2}$ \\
\hline 1.Stressed & 312 & 1 & 5 & 2,53 & 1,001 \\
\hline $\begin{array}{c}\text { 2.Challenged-by-the-difficulty-of-the- } \\
\text { Situation }\end{array}$ & 312 & 1 & 5 & 3,02 &, $\mathbf{8 9 8}$ \\
\hline 3.Threatened & 312 & 1 & 5 & 2,18 & 1,014 \\
\hline 4.Confused & 312 & 1 & 5 & 2,62 &, 676 \\
\hline 5.Satisfied-to-benefit-from-the-situation & 312 & 2 & 5 & 3,92 &, 767 \\
\hline 6.Angry & 312 & 1 & 5 & 1,99 &, $\mathbf{9 8 1}$ \\
\hline 7.Anxious & 312 & 1 & 5 & 2,45 &, 708 \\
\hline 9.Self-empowered & 312 & 1 & 5 & 3,50 &, 699 \\
\hline
\end{tabular}

\subsubsection{Threats and challenges towards MOOCs}

There are various opportunities that technology provides for teacher's professional development. Teachers can easily, through MOOCs programs, have access to a massive range of courses with reference to the subject that meets their interests regardless of the place they are in. However, these advantages are not free from some challenges and threats regarding MOOCs' use for continuing professional development. Descriptive statistical results indicated that there is a multiplicity of threats and challenges that hinder English teachers from MOOCs' use for their continuing professional development, namely stress, technophobia, and anxiety. These factors scored the highest, as evinced in Table 12 below. Moreover, the comparison of means and variance indicates that the predictors explained earlier, such as age, teaching experience and others, have a remarkable impact on teachers ' use of MOOCs programs for their professional development.

\section{Conclusions and Recommendations for Practice}

MOOCs programs are helpful and useful resources for teacher's professional growth, at least from Moroccan teachers of English standpoint, especially if we take consideration into the challenge faced within educational systems associated with providing capacity and skills development to teachers regularly. However, not all teachers have similar challenges nor have they the same level of preparedness to adopt technology for continuing professional development. The findings obtained in the current paper show that there are many factors that affect teachers' acceptance and readiness regarding MOOCs' use for professional development. First, a considerable number of Moroccan teachers appear to have a positive attitude and more in-depth knowledge towards MOOCs for continuing professional development. They consider MOOCs a reliable tool to complete, reinforce and bring up-to-date to their teaching skills and knowledge for free and under an ubiquitous way that makes it effortless to study for those who do not have enough time or for those who cannot afford it to travel to places where such face-to-face training opportunities take place. Generally, in-person trainings for teachers of English take place in big cities such as Rabat, Casablanca and Marrakech. In the present paper, MOOCs proved to be efficient tools for teachers living and working in remote areas. For example, teachers belonging to the region of Khenifra-Beni-Mellal scored the highest in respect of MOOCs' use for teacher's professional development based on region. Hence, three major elements are worth mentioning since they support this current study: First, there are noticeable deficiencies in teachers' training. Second, MOOCs can be utilised as a substitute to traditional training or a complement to teachers' training. Third, the gap exists between onsite teachers' training and continuing professional development. Accordingly, a MOOC program about Sciences Education could play a vital role in ameliorating initial and continuous teacher training, both onsite and open universities.

Furthermore, education decision-makers could include more teachers' training opportunities to experiment the felicities of this sort of professional development that takes place in teachers' training centers. It would be of great benefit to incorporate modules (subjects) that are taught in blended learning form while English teachers are in the pre-service training. Finally, MOOCs could be also used to encourage collaboration between schools and their surrounding environment. It can turn into a meeting environment where the exchange of opinions, experiences, methodologies might occur, and teachers receive training from other teachers in some curricular facets which may be handy and innovatory. 


\section{REFERENCES}

[1] Bandura, A. Self-Efficacy Mechanism in Human Agency. American Psychologist. DOI: 10.1037/0003-066X.37.2.122. 37,122-147, 1982.

[2] Choy, S. P., Chen, X., \& Bugarin, R. Teacher Professional Development in 1999-2000: What Teachers, Principals, and District Staff Report. Statistical Analysis Report. NCES 2006-305. National Center for Education Statistics, 2006.

[3] COSEF. Charte National d'Education et de Formation. Retrieved from http://www.esi.ac.ma/Dossiers/2015071309 0757.pdf, 17, 1999.

[4] Cox, M. J. Technology enriched school project-The impact of information technology on children's learning. Computers \& Education, 21(1-2), 41-49, 1993.

[5] Cox, M., Rhodes, V., \& Hall, J. The use of computer assisted learning in primary schools: some factors affecting the uptake. Computers \& Education, 12(1), 173-178, 1988.

[6] Darling-Hammond, L., Wei, R. C., Andree, A., Richardson, N., \& Orphanos, S. Professional learning in the learning profession. Washington, DC: National Staff Development Council, 12, 2009.

[7] Davis, F. Perceived Usefulness, Perceived Ease of Use, and User Acceptance of Information Technology. MIS Quarterly. DOI: $10.2307 / 249008.13,319-340,1989$

[8] Davis, Fred \& Bagozzi, Richard \& Warshaw, Paul. User Acceptance of Computer Technology: A Comparison of Two Theoretical Models. Management Science. DOI: 10.1287/mnsc.35.8.982. 35, 982-1003, 1989.

[9] Dong, G.L., Ryu, K.S., Bashir, M. et al. 'Discovering medical knowledge using association rule mining in young adults with acute myocardial infarction', Journal of Medical Systems, Vol. 37, No. 2, pp.1-10, 2013.

[10] Emanuel, E. J. Online education: MOOCs taken by educated few. Nature, 503(7476), 342, 2013.

[11] Evans, L. What is teacher development? Oxford review of education, 28(1), 123-137, 2002.

[12] Gaible, E., \& Burns, M. Using technology to train teachers: Appropriate uses of ICT for teacher professional development in developing countries. Washington, DC:
infoDev/ World Bank, 2005. Online available: http://www.infodev.org/en/Publication.13.html

[13] Hicks, C. Why MOOCs are great for teacher development. Online available: http://www.edudemic.com/5-moocs-educ ators-should-take-as-students/, 2015.

[14] Jiang, Z.X., Zhang, Y. and Li, XM' Learning behavior analysis and prediction based on MOOC data', Journal of Computer Research and Development, Vol. 52, No. 3, pp.614-628, 2015.

[15] Jobe, W., Östlund, C., \& Svensson, L. In M. Searson \& M. Ochoa (Eds.), Proceedings of SITE 2014--Society for Information Technology \& Teacher Education International Conference (pp. 1580-1586). Jacksonville, Florida, United States: Association for the Advancement of Computing in Education (AACE). Online available: https://www.oerknow ledgecloud.org/archive/proceeding_130997\%20(3).pdf , 2014.

[16] Marquis, J. Why MOOCs are good for teacher professional development. Online available: http://www.onlineuniversiti es.com/blog/2013/05/why-moocs-aregood-for-teacher-profe ssional-development, 2013.

[17] Richard, A. How do MOOCs fit into professional training? Online available: http://www.colloquium-group.com/how-d o-moocs-fit-into-professionaltraining/?lang=en, 2014.

[18] Rogers, E. M., \& Shoemaker, F. F. Communication of Innovations; A Cross-Cultural Approach, 1971.

[19] Watson, D. M. Pedagogy before technology: Re-thinking the relationship between ICT and teaching. Education and Information Technologies, 6(4), 251-266, 2001.

[20] Woodrow, J. E. The influence of programming training on the computer literacy and attitudes of pre-service teachers. Journal of Research on Computing in Education, 25(2), 200-218, 1992.

[21] Wu, Y-F., Yuan, M-H. and Peng, Z-C. 'Research on the cultivation of students' autonomous learning ability based on MOOC-based network interactive teaching', Int. J. Continuing Engineering Education and Life-Long Learning, Vol. 29, Nos. 1/2, pp.72-86, 2019.

[22] Zhaolin Ji, Yanhua Cao. A Prospective Study on the Application of MOOC in Teacher Professional Development in China. Universal Journal of Educational Research, 4(9), 2061 - 2067. DOI: 10.13189/ujer.2016.040917, p.2, 2016. 